\title{
Development of hydroxyapatite-ciprofloxacin bone-implants using "Quality by design«
}

\author{
AMIT KUMAR NAYAK* \\ BIBEK LAHA \\ KALYAN KUMAR SEN \\ Department of Pharmaceutics \\ Gupta College of Technological \\ Sciences, Asansol-713301, India
}

Accepted December 15, 2010

\begin{abstract}
The present study deals with the development of hydroxyapatite (HAp)-ciprofloxacin bone-implants using the "Quality by design « approach. The effect of various synthesis parameters like drug amount added in the process, stirring speed and addition rate of orthophosphoric acid in the synthesis on drug concentration in the HAp-ciprofloxacin system synthesized by the precipitation technique using $2^{3}$ factorial design was analyzed. Optimization methodology utillizing the first-order polynomial equation was used to search for optimal drug concentration in the HAp-ciprofloxacin implant system. The observed responses coincided well with the predicted values from the optimization technique. New implants were manufactured using various HAp-ciprofloxacin composites and $1.5 \%(\mathrm{~m} / \mathrm{V})$ guar gum as a binder. Characterization of the delivery system was done by XRPD, FTIR spectroscopy and SEM. Even at highest drug concentration $(76.6 \pm 0.5 \%, m / m)$, ciprofloxacin was present in noncrystalline state. The in vitro ciprofloxacin release from various bone-implants was sustained for several weeks and the drug release pattern correlated well with the Korsmeyer-Peppas model.
\end{abstract}

Keywords: hydroxyapatite, ciprofloxacin, bone-implant, "Quality by design«, osteomyelitis

Prolonged administration of systemic antibiotics is usual in chronic osteomyelitis treatment (1). But, local implantable delivery with sustained antibiotic release may offer considerable advantages over the traditional method of therapy by producing an effective local antibiotic concentration at the diseased site, with the limitation of systemic exposure to antibiotics maintaining low systemic side effects (2).

Hydroxyapatite $\left(\mathrm{HAp},\left[\mathrm{Ca}_{10}\left(\mathrm{PO}_{4}\right)_{6}(\mathrm{OH})_{2}\right]\right)$ is one of the widely used bioceramics in various biomedical applications, mainly in orthopedics and dentistry, due to its close similarity to inorganic mineral components of bones and teeth (3). Because of its biocom-

*Correspondence; e-mail: amitkrnayak@yahoo.co.in 
patibility and bone-bonding property, HAp has been used as a safe matrix in the bone drug delivery $(4,5)$. It also offers high binding affinity for a variety of pharmacological substances such as antibiotics, hormones, steroids, etc. (6-8). This has opened the potential of using HAp to deliver various pharmacological substances in many clinical applications.

Ciprofloxacin is a fluroquinolone derivative, widely used in osteomyelitis because of its favorable penetration and bactericidal effect on all the probable osteomyelitis pathogens (9). An investigation of the HAp-ciprofloxacin system was performed by Pham et al. based on the precipitation and spray drying techniques (10). But, the drug release kinetics from these delivery systems (sustained release of ciprofloxacin for a few days only) were not as satisfactory as expected from an implantable system for bone delivery. The effectiveness of an antibiotic therapy to treat bone infections involves irrigating the infected site by the therapeutic level of antibiotic concentration for several weeks (11). In our initial investigation, we found high ciprofloxacin concentration (up to $76.6 \pm 0.5 \%$, $\mathrm{m} / \mathrm{m}$ ) in an HAp-based system synthesized by the precipitation technique and by varying synthesis parameters such as drug amount added and addition rate of orthophosphoric acid (10). In this case, the addition rate of orthophosphoric acid was slower $(1 \mathrm{~mL}$ $\mathrm{min}^{-1}$ and $0.5 \mathrm{~mL} \mathrm{~min}^{-1}$ ) in comparison with earlier literature reports on the precipitation technique (9), and thus we have formulated HAp-ciprofloxacin minipellets for bone-implantable delivery by compressing synthesized HAp-ciprofloxacin powders. The in vitro ciprofloxacin release from these minipellets was slow and sustained for several weeks. In the present investigation, we have attempted to increase drug concentration in implants, which will reduce the total mass and size of implants. This may work like small surgery and decreases hospitalization period. Therefore, in the present investigation, we have attempted to analyze the effect of various synthesis parameters such as the drug amount added in the process, stirring speed and addition rate of orthophosphoric acid in the synthesis on drug concentration in the HAp-system. The precipitation technique using $2^{3}$ factorial design was used to develop HAp-ciprofloxacin bone-implants "Quality by design $(\mathrm{QbD})$ «. QbD encompasses designing and developing formulations and manufacturing processes that ensure ensure predefined product specifications. An important part of $\mathrm{QbD}$ is to understand how process and formulation parameters affect the product quality and subsequent optimization of these parameters with respect to final specifications (12). Also, we have used guar gum, a natural biodegradable material, as a binder to manufacture new HAp-ciprofloxacin bone-implants, which was not common by used in previous investigations (9-11).

\section{EXPERIMENTAL}

\section{Materials}

Ciprofloxacin hydrochloride was a generous gift from Dr. Reddy's Laboratories (India). Calcium hydroxide (Qualigens Fine Chemicals, India), orthophosphoric acid (Qualigens Fine Chemicals, India) and guar gum (HiMedia Laboratories, India) were used. All other chemicals were of analytical grade. 


\section{Methods}

Experimental design. - A three-factor, two-level factorial design $\left(2^{3}\right)$ was employed for optimization, with the drug amount added in the process $\left(X_{1}\right)$, stirring speed $\left(X_{2}\right)$ and addition rate of orthophosphoric acid in the synthesis $\left(X_{3}\right)$ as three prime selected independent variables. They were varied at two levels, low level $(-1)$ and high level $(+1)$. The percentage of drug in the HAp-system was used as a dependent variable. Design-Expert ${ }^{\circledR}$ DX 7 software was used for the generation and evaluation of the statistical experimental design. The design matrix including the response (drug load) is shown in Table II.

Synthesis of HAp-ciprofloxacin composites. - The HAp-ciprofloxacin composites were prepared by the precipitation technique. In brief, $50 \mathrm{~mL}$ of aqueous suspension of 0.5 mol L ${ }^{-1}$ calcium hydroxide was prepared and vigorously stirred for $10 \mathrm{~min} .50 \mathrm{~mL}$ of 0.3 mol L ${ }^{-1}$ orthophosphoric acid was slowly added into the calcium hydroxide suspension. Then, the drug was added and $\mathrm{pH}$ (10.5) was carefully adjusted with $1 \mathrm{~mol} \mathrm{~L}^{-1}$ ammonium hydroxide. The suspension was well stirred using a magnetic stirrer for $30 \mathrm{~min}$ and aged overnight at room temperature. The precipitate was subjected to vacuum filtering using a Büchner funnel, repeatedly washed with deionized water and filtered again. The precipitates was dried at room temperature for 48 hours. Dried lumps of composites were ground using clean mortars and pestles.

Determination of drug concentration and drug loading. - Filtrates of the suspensions of HAp-ciprofloxacin composites, which were obtained after washing with deionized water, were taken and analyzed to determine the drug loading and drug incorporation efficiencies. Absorbance values were measured from filtrate dilutions of different formulations at $274 \mathrm{~nm}$ using a UV-VIS spectrophotometer (Thermo Spectronic UV-1, USA). Drug concentration and drug loading were calculated.

Manufacturing HAp-ciprofloxacin bone-implants. - HAp-ciprofloxacin composites (2 g) were mixed with $2.5 \mathrm{~mL}$ of $1.5 \%(\mathrm{~m} / \mathrm{V})$ aqueous solution of guar gum to make a smooth paste and were then poured into $2.5-\mathrm{mm}$ diameter cylindrical moulds using an extruder syringe. After hardening, cylindrical rods (diameter $2.5 \mathrm{~mm}$ ) were removed from moulds and dried at room temperature for 24 hours. The cylindrical rods were cut into pellet-sized implants. The geometry of the implants was cylindrical with an average length of $2 \mathrm{~mm}$ and diameter of $2.5 \mathrm{~mm}$.

\section{Characterization of the HAp-ciprofloxacin delivery system}

$X$-ray powder diffraction (XRPD). - Samples were exposed to $\mathrm{CuK} \alpha$ radiation $(35 \mathrm{kV}$ $\times 30 \mathrm{~mA}$ ) in a wide-angle X-ray diffractomter (SEIFERT X-Ray Diffractometer, XRD 3000 $\mathrm{P}, \mathrm{RICH}$ SEIFERT \& Co., Germany). The instrument was operated in the step-scan mode with increments of $0.050^{\circ} 2 \theta$. The angular range was 5 to $40^{\circ} 2 \theta$, and counts were accumulated for 1 second at each step.

Fourier transform infrared (FTIR) spectroscopy. - The samples were triturated to powder and analyzed in $\mathrm{KBr}$ pellets using a Perkin Elmer Spectrum RX I spectrometer (Perkin Elmer, USA). 
Scanning electron microscopy (SEM). - The samples were gold coated in an ion sputter (Hitachi E1010, Japan) and their microstructures were examined with a scanning electron microscope (Hitachi S3400, Japan).

In vitro release of ciprofloxacin from implants. - Samples containing 5 bone-implants of each formulation were placed in Falcon tubes containing $5 \mathrm{~mL}$ of $\mathrm{pH} 7.4$ phosphate buffer saline (PBS) at $37 \pm 0.5^{\circ} \mathrm{C}$. Elution fluids were collected and the same volume of fresh buffer was replaced at regular intervals. Collected elution fluids were used for determination of antibiotic concentration at $271 \mathrm{~nm}$.

\section{Data analysis}

The purpose for using a full factorial experimental design was to conduct a comprehensive study of the effect of process parameters and their interactions using a suitable statistical tool (Design-Expert ${ }^{\circledR}$ DX 7 Software) by applying one-way ANOVA. Individual response parameters were evaluated using the F-test. Mathematical modeling was carried out to obtain a first-order polynomial equation depending on significant influences of the three factors $\left(X_{1}, X_{2}\right.$ and $\left.X_{3}\right)$ of the factorial design model using the following equation:

$$
Y=b_{0}+b_{1} X_{1}+b_{2} X_{2}+b_{3} X_{3}+b_{4} X_{1} X_{2}+b_{5} X_{1} X_{3}+b_{6} X_{2} X_{3}+b_{7} X_{1} X_{2} X_{3}
$$

where $Y$ is the dependent variable, while $b_{0}$ is the intercept, $b_{1}, b_{2}, b_{3}, b_{4}, b_{5}, b_{6}$ and $b_{7}$ are regression coefficients; $X_{1} X_{2}, X_{2} X_{3}, X_{1} X_{3}$ and $X_{1} X_{2} X_{3}$ are interactions between the main effects.

\section{Release kinetics modelling}

The in-vitro ciprofloxacin release data from implants were evaluated kinetically using various mathematical models, such as zero-order, first-order, Higuchi, Hixon-Crowell and Korsmeyer-Peppas model $(9,13-14)$ :

- for zero-order kinetics: $F=k_{\mathrm{o}} t$, where $F$ represents the fraction of drug released in time $t$, and $k_{\mathrm{o}}$ is the apparent release rate constant or zero-order release constant;

- for first-order kinetics: $\ln (1-F)=-k_{1} t$, where $F$ represents the fraction of drug released in time $t$, and $k_{1}$ is the first-order release constant;

- for Higuchi model: $F=k_{\mathrm{H}} t^{1 / 2}$, where $F$ represents the fraction of drug released in time $t$, and $k_{\mathrm{H}}$ is the Higuchi dissolution constant;

- for Hixon-Crowell model: $W_{\mathrm{o}}^{1 / 3}-W_{\mathrm{t}}^{1 / 3}=k_{\mathrm{s}} t$, where $W_{\mathrm{o}}$ is the initial amount of the drug in composites, $W_{t}$ is the remaining amount of the drug in composites at $t$, and $k_{\mathrm{S}}$ is the constant incorporating the surface volume relation (dividing the above equation by $W_{\mathrm{o}}^{1 / 3}$ and simplifying: $(1-F)^{1 / 3}=1-k_{\mathrm{E}} t$, where $F=1-\left(W_{\mathrm{t}} / W_{\mathrm{o}}\right)$ and $F$ represents the drug dissolved fraction at time $t$, and $k_{\mathrm{E}}$ is the release constant).

- for Korsmeyer-Peppas model: $F=k_{\mathrm{P}} t^{n}$, where $F$ represents the drug fraction released in time $t, k_{\mathrm{P}}$ is the rate constant and $n$ is the diffusional exponent; this indicates the drug release mechanism. 


\section{RESULTS AND DISCUSSION}

\section{Factorial design}

Hydroxyapatite-ciprofloxacin composites were prepared by the precipitation technique according to the $2^{3}$ factorial design. For the $2^{3}$ factorial design, a total of 8 experimental formulations were prepared for 3 factors, the drug amount added in the process, stirring speed and addition rate of orthophosphoric acid in the synthesis, at 2 levels (high and low). Values of the drug concentration data in the $2^{3}$ factorial design (Table I) were fitted to a first-order polynomial model. Our model equation became:

$$
\begin{gathered}
Y=3.98889+28.88869 X_{1}-0.00940 X_{2}-0.05889 X_{3}+0.01010 X_{1} X_{2}-0.20869 X_{1} X_{3}+ \\
+0.000005 X_{2} X_{3}+0.0000425 X_{1} X_{2} X_{3}
\end{gathered}
$$

The results of ANOVA, as shown in Table II, indicated that the model was significant for all response parameters investigated with an $F$-value of $1251.65(p<0.0216)$ and $R^{2}$ value of 0.9999 . Model simplification was carried out by eliminating non-significant parameters in the polynomial equation resulting from the multiple regression analysis, giving:

$$
Y=3.98889+28.88869 X_{1}-0.05889 X_{3}-0.20869 X_{1} X_{3}
$$

A numerical optimization technique using the desirability approach was employed to develop new formulations with desired responses (desired quality). A constraint to

\begin{tabular}{|c|c|c|c|c|}
\hline \multirow[t]{2}{*}{$\begin{array}{l}\text { Formulation } \\
\quad \text { code }\end{array}$} & $\begin{array}{l}\text { Drug amount added } \\
\text { in the synthesis }(\mathrm{g})\end{array}$ & $\begin{array}{l}\text { Stirring speed } \\
\quad(\mathrm{rpm})\end{array}$ & $\begin{array}{l}\text { Addition rate of } \\
\text { orthophosphoric acid in } \\
\text { the synthesis }\left(\mathrm{mL} \mathrm{min} \mathrm{min}^{-1}\right)\end{array}$ & $\begin{array}{c}\text { Response } \\
\text { (drug concentration) } \\
(\%, m / m)^{\mathrm{a}}\end{array}$ \\
\hline & $\left(X_{1}\right)$ & $\left(X_{2}\right)$ & $\left(X_{3}\right)$ & \\
\hline F-HCip/1 & $1(+1)$ & $1000(+1)$ & $100(+1)$ & $11.9 \pm 0.7$ \\
\hline F-HCip /2 & $1(+1)$ & $600(-1)$ & $1(-1)$ & $33.2 \pm 0.4$ \\
\hline F-HCip/3 & $0.5(-1)$ & $600(-1)$ & $100(+1)$ & $2.6 \pm 0.1$ \\
\hline F-HCip/4 & $0.5(-1)$ & $1000(+1)$ & $1(-1)$ & $14.1 \pm 0.4$ \\
\hline F-HCip/5 & $1(+1)$ & $1000(+1)$ & $1(-1)$ & $33.2 \pm 0.3$ \\
\hline F-HCip/6 & $1(+1)$ & $600(-1)$ & $100(+1)$ & $9.4 \pm 0.2$ \\
\hline F-HCip/7 & $0.5(-1)$ & $1000(+1)$ & $100(+1)$ & $2.5 \pm 0.1$ \\
\hline F-HCip/8 & $0.5(-1)$ & $600(-1)$ & $1(-1)$ & $15.6 \pm 0.5$ \\
\hline
\end{tabular}

Table I. $2^{3}$ full factorial design (coded values in brackets) with responses for different HAp-ciprofloxacin composites

$[(+1)=$ high level, $(-1)=$ low level $]$

a Mean \pm SEM, $n=3$. 
A. Kumar Nayak et al:: Development of hydroxyapatite-ciprofloxacin bone-implants using "Quality by design«, Acta Pharm. 61 (2011) 25-36.

Table II. Summary of ANOVA for the response parameter (ciprofloxacin concetration) in HAp-ciprofloxacin composites by $2^{3}$ factorial design experiment

\begin{tabular}{lcccccc}
\hline Source & Sum of squares & d.f. & Mean square & $F$-value & \multicolumn{1}{c}{$p$-value } & $R^{2}$ \\
\hline Model & 1015.34 & 6 & 169.22 & 1251.65 & $0.0216(\mathrm{~S})$ & 0.9999 \\
$X_{1}$ & 349.27 & 1 & 349.27 & 2583.38 & $0.0125(\mathrm{~S})$ & \\
$X_{2}$ & 0.14 & 1 & 0.14 & 1.00 & $0.5000(\mathrm{NS})$ & \\
$X_{3}$ & 608.66 & 1 & 608.66 & 4501.89 & $0.0095(\mathrm{~S})$ & \\
$X_{1} X_{2}$ & 2.04 & 1 & 2.04 & 15.09 & $0.1604(\mathrm{NS})$ & \\
$X_{1} X_{3}$ & 53.35 & 1 & 53.35 & 394.63 & $0.0320(\mathrm{~S})$ & \\
$X_{2} X_{3}$ & 1.88 & 1 & 1.88 & 13.92 & $0.1667(\mathrm{NS})$ & \\
$X_{1} X_{2} X_{3}$ & 1.96 & 1 & 1.96 & 14.64 & $0.1635(\mathrm{NS})$ & \\
\hline
\end{tabular}

d.f. - degrees of freedom; S - significant; NS - not significant

maximizing the ciprofloxacin concentration in the HAp-system was to set the goal to locate the optimum settings of independent variables in the new formulations by $\mathrm{QbD}$, and these new formulations were formulated using the optimum settings of independent variables (Table III). QbD stresses the need to thoroughly understand the critical process parameters with the aim of achieving successful product development with predefined quality attributes (15). Critical quality attributes are the properties that need to be controlled as they affect either patent safety or efficacy (16). Optimized HAp-ciprofloxacin composites were evaluated for ciprofloxacin concentration. Table III lists the values of the observed responses and those predicted by the mathematical model. The graph of plotting the observed values of drug loading of optimized HAp-ciprofloxacin composite formulations $v$ s. predicted values using the mathematical model (figures not shown) shows the $R^{2}$ value of 0.9986 . This reveals that the mathematical model obtained by the $2^{3}$ factorial experimental design to produce the optimized response (here drug concentration, $\%, m / m$ ) was well fitted.

Increase in drug concentration and also in drug loading efficiency was observed at the lower rate of orthophosphoric acid addition in the synthesis. Formulation F-HCip/10

Table III. Values of independent variables for maximizing the ciprofloxacin concentration in HAp-ciprofloxacin composites using the numerical optimization technique

\begin{tabular}{cccccc}
\hline \multirow{2}{*}{$\begin{array}{c}\text { Formulation } \\
\text { code }\end{array}$} & $\begin{array}{c}\text { Drug amount } \\
\text { added in the } \\
\text { synthesis }(\mathrm{g})\end{array}$ & $\begin{array}{c}\text { Stirring } \\
\text { speed } \\
(\mathrm{rpm})\end{array}$ & $\begin{array}{c}\text { Addition rate of } \\
\text { orthophosphoric } \\
\text { acid in the synthesis } \\
\left(\mathrm{mL} \mathrm{min}^{-1}\right)\end{array}$ & Drug concentration $(\%, m / m)$ \\
\cline { 2 - 6 } & $\left(\mathrm{X}_{1}\right)$ & $\left(\mathrm{X}_{2}\right)$ & $\left(\mathrm{X}_{3}\right)$ & Observed values $^{\mathrm{a}}$ & Predicted values \\
\hline F-HCip/9 & 2 & 600 & 0.5 & $64.1 \pm 0.6$ & 61.5 \\
F-HCip $/ 10$ & 2.5 & 600 & 1 & $75.2 \pm 0.6$ & 75.6 \\
F-HCip/11 & 2.5 & 600 & 0.5 & $76.6 \pm 0.5$ & 75.9 \\
\hline
\end{tabular}

a Mean \pm SEM, $n=3$. 
showed high concentration of ciprofloxacin of $75.2 \pm 0.6$ and $76.6 \pm 0.5 \% \mathrm{~m} / \mathrm{m}$ with high drug loading efficiency of $85.6 \pm 0.1 \% \mathrm{~m} / \mathrm{m}$ and $87.4 \pm 0.2 \% \mathrm{~m} / \mathrm{m}$, respectively (Tables III and Table IV).

\section{XRPD}

X-ray powder diffraction profiles of standard ciprofloxacin hydrochloride, HAp-ciprofloxacin composites and HAp blank powders are shown in Fig. 1. XRPD profiles of HAp-ciprofloxacin composites did not show any major differences in characteristic peaks for HAp from that of HAp blank powder, indicating that the drug (here ciprofloxacin) might be present in a noncrystalline form or in solid solution in the HAp-system. Again, it clearly appeared that the XRPD pattern of standard ciprofloxacin hydrochloride showed significantly different diffraction features them that of HAp-ciprofloxacin composites and these differences might be due to presence of polycrystalline ciprofloxacin in the standard ciprofloxacin hydrochloride samples.

\section{FTIR}

Fourier transform infrared spectra of HAp blank powders, guar gum, standard ciprofloxacin hydrochloride, HAp-ciprofloxacin composites, and HAp-ciprofloxacin bone-implants are presented in Fig. 2. Synthesized HAp blank powder and standard ciprofloxacin hydrochloride samples were used for comparison. The FTIR spectrum of synthesized HAp blank powder showed the characteristic peaks, namely $\mathrm{PO}_{4}$ narrow peak at 963 $\mathrm{cm}^{-1}$, the $\mathrm{PO}_{4}$ peak at $1039 \mathrm{~cm}^{-1}, \mathrm{PO}_{4}$ peaks at 604 and $564 \mathrm{~cm}^{-1}$, and the $\mathrm{OH}$ peak at 668 $\mathrm{cm}^{-1}$, as expected (17). Incorporation of ciprofloxacin into the HAp-system led to emergence of a characteristic peak $\left(1625 \mathrm{~cm}^{-1}\right.$ for $\mathrm{C}=\mathrm{O}$ in ciprofloxacin) (18). In the FTIR spectra of HAp-ciprofloxacin composites and HAp-ciprofloxacin bone-implants, the charac-

Table IV. Drug loading efficiency of various formulations of HAp-ciprofloxacin composites prepared by precipitation technique

\begin{tabular}{cc}
\hline Formulation code & Drug loading efficiency $(\%)^{\mathrm{a}}$ \\
\hline F-HCip / & $29.8 \pm 0.6$ \\
F-HCip / & $85.7 \pm 0.7$ \\
F-HCip/3 & $12.7 \pm 0.6$ \\
F-HCip /4 & $72.2 \pm 0.3$ \\
F-HCip /5 & $83.0 \pm 0.4$ \\
F-HCip /6 & $26.3 \pm 1.3$ \\
F-HCip /7 & $78.7 \pm 0.2$ \\
F-HCip /9 & $86.6 \pm 5.7$ \\
F-HCip /10 & $85.6 \pm 0.1$ \\
F-HCip /11 & $87.4 \pm 0.2$ \\
\hline
\end{tabular}

a Mean \pm SEM, $n=3$. 

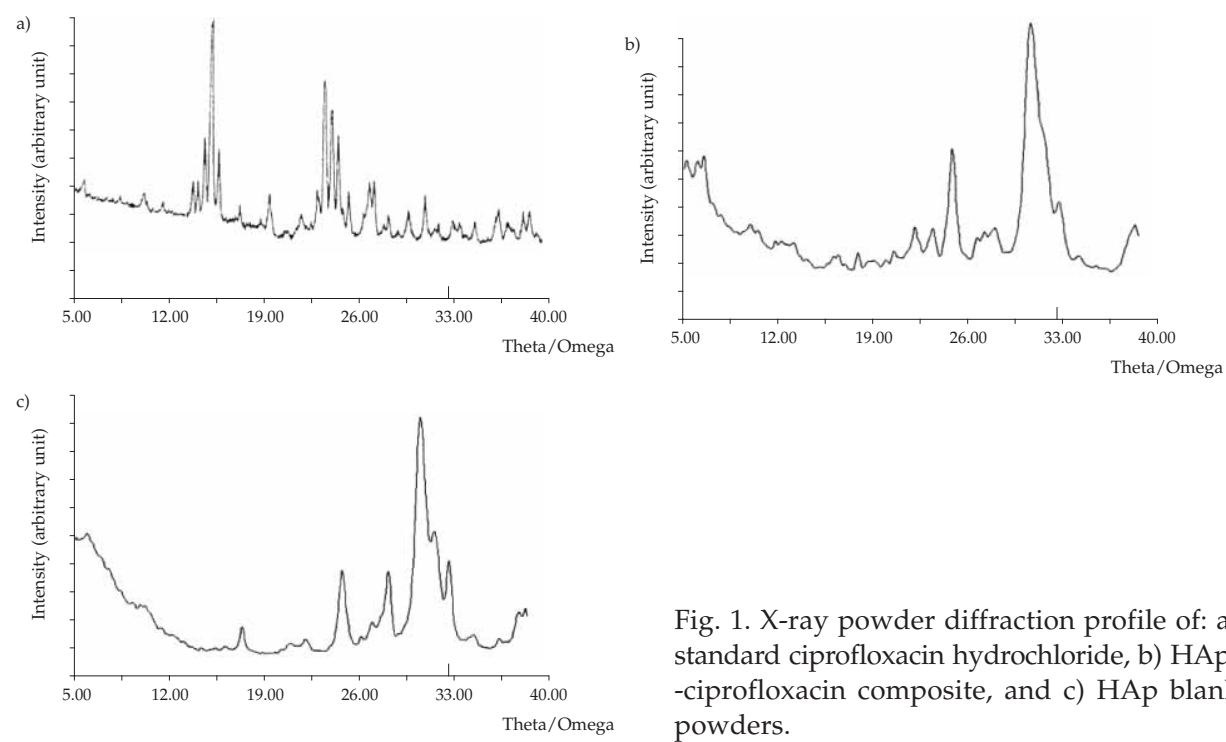

Fig. 1. X-ray powder diffraction profile of: a) standard ciprofloxacin hydrochloride, b) HAp-ciprofloxacin composite, and c) HAp blank powders.

teristic peaks of ciprofloxacin were the same as in the standard sample or very slight shifting of these peaks occurred. This confirms the presence of ciprofloxacin without or in very minute interaction.

\section{SEM}

Scanning electron microscopy images of HAp blank powders are presented in Fig. 3. The images were present as rough, granular or dense aggregates. The particles showed different shapes, such as short and long columns, thick plates and needle. The SEM photographs of synthesized powders suggest the typical apatite appearance (19). The microstructure of HAp blank powders synthesized using $100 \mathrm{~mL} \mathrm{~min}^{-1}$, addition rate of

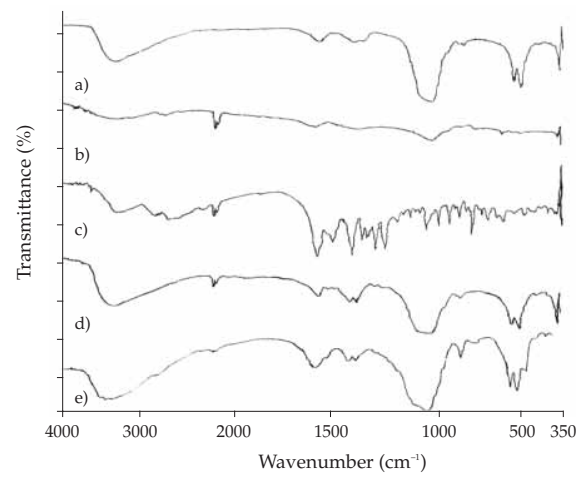

Fig. 2. FT-IR spectra of: a) HAp blank powder, b) guar gum, c) ciprofloxacin hydrochloride, d) HAp-ciprofloxacin composite and e) HAp-ciprofloxacin bone-implant (5). 
orthophosphoric acid was comparatively dense; the particles were of different shapes (short and long columns, thick and needle-like plates). On the other hand, $0.5 \mathrm{~mL} \mathrm{~min}{ }^{-1}$ adition rate of orthophosphoric acid resulted in relatively small particles spherical in shape with rough surfaces. The SEM photograph of HAp-ciprofloxacin composites synthesized using $0.5 \mathrm{~mL} \mathrm{~min}^{-1}$ of orthophosphoric acid addition rate (F-HCip/11) was found to be comparatively similar to that of HAp blank powders synthesized using the same addition rate of orthophosphoric acid. The microstructure of both samples probably helped provide more surface area to adsorb drug molecules, which increased the drug concentration and loading into the HAp-system.

Various HAp-ciprofloxacin bone-implants $(2 \mathrm{~mm} \times 2.5 \mathrm{~mm})$ were prepared using various synthesized HAp-ciprofloxacin composites and $1.5 \%(\mathrm{~m} / \mathrm{V})$ guar gum as a binder. Thus formulated implants were evaluated for in vitro drug release in PBS (pH 7.4). The in vitro ciprofloxacin release in PBS ( $\mathrm{pH} 7.4)$ from the bone-implants was followed for 10 (Fig. 4). All implants (except F-HCip/3 and F-HCip/7) exhibited sustained release of ciprofloxacin for several weeks. Formulations F-HCip/10 and F-HCip/11 showed more sustained drug release than the others. These two formulations were prepared using HAp-ciprofloxacin composites with comparatively higher drug concentration and drug loadings efficiency. This indicates that the release rate of ciprofloxacin from these
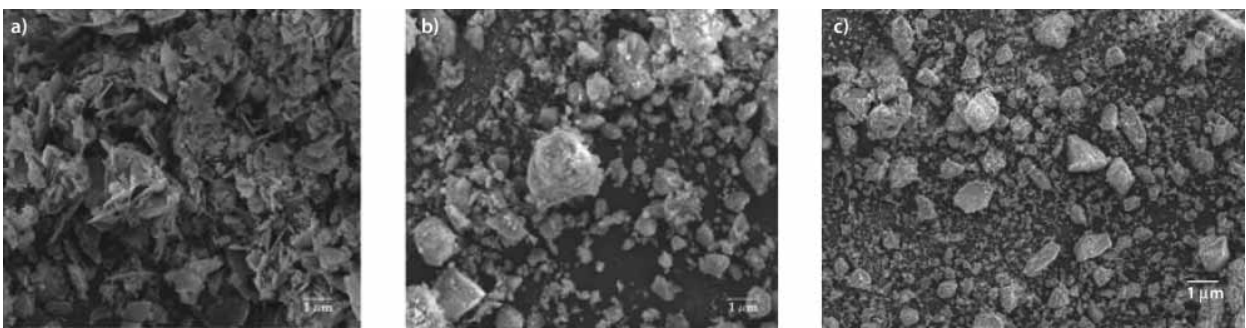

Fig. 3. SEM images of HAp blank powders synthesized using the addition rate of orthophosphoric acid: a) $100 \mathrm{~mL} \mathrm{~min}^{-1}$, b) $0.5 \mathrm{~mL} \mathrm{~min}^{-1}$ and c) HAp-ciprofloxacin composite using the addition rate of orthosphoric acid of $0.5 \mathrm{~mL} \mathrm{~min}^{-1}$ (F-HCip/11).

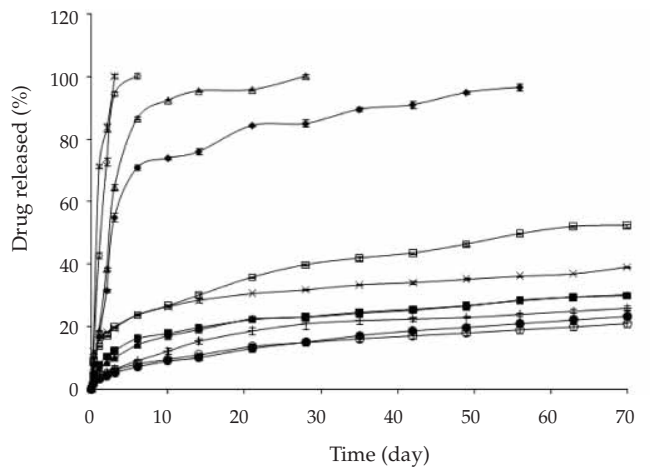

$$
\begin{aligned}
& \rightarrow \text { F-HCip } / 1 \\
& \rightarrow \text { F-HCip } / 2 \\
& \rightarrow \text { F-HCip } / 3 \\
& \rightarrow \text { F-HCip } / 4 \\
& \rightarrow \text { F-HCip } / 5 \\
& \rightarrow \text { F-HCip } / 6 \\
& \rightarrow \text { F-HCip } / 7 \\
& \text { * F-HCip } / 8 \\
& + \text { F-HCip } / 9 \\
& \rightarrow \text { F-HCip } / 10 \\
& - \text { F-HCip } / 11 \\
& \hline
\end{aligned}
$$

Fig. 4. In vitro drug release profiles from F-HCip/ 1 to F-HCip/ 11 bone-implants (mean \pm SEM, $n=3$ ). 
implants depended on the amount of drug concentration and drug load, as expected. Thus, the pattern of ciprofloxacin release from highly loaded HAp-ciprofloxacin bone-implants may enable clinicians to achieve and maintain a therapeutic drug concentration in the infected bone tissue area for a long period of time.

In order to predict and correlate the release behavior of ciprofloxacin from different implants, it is necessary to fit the release data into a suitable mathematical model. The results of curve fitting of in vitro data for various implants prepared from optimized HAp-ciprofloxacin composites into different mathematical models $(9,13-14)$ are given in Table V. The drug release pattern of implants investigated in this research correlated well the Korsmeyer-Peppas model over a period of 21 days. Korsmeyer-Peppas model was employed in the in vitro drug release behavior analysis of various pharmaceutical formulations to distinguish between two competing release mechanisms, a Fickian (non-steady) diffusional release when $n \leq 0.45$ and a case-II transport (zero-order kinetics) when $n \geq 0$ (20). It would appear that the value of $n$ (Korsmeyer-Peppas model) for three optimized formulations was lower than 0.45 . We are inclined to believe that the mechanism of ciprofloxacin release from implants followed Fickian diffusion. Thus, the release of ciprofloxacin from these HAp implants was mostly diffusion based; relaxational release was not predominant.

Table V. Curve fitting of the in vitro ciprofloxacin release from optimized HAp-ciprofloxacin composite implants $^{a}$

\begin{tabular}{lcccc}
\hline Mathematical model & Formulation code & F-HCip $/ 9$ & F-HCip $/ 10$ & F-HCip $/ 11$ \\
\hline Zero-order & $k_{\mathrm{o}}\left(\right.$ day $\left.^{-1}\right)$ & 0.0079 & 0.0060 & 0.0054 \\
First-order & $R^{2}$ & 0.9515 & 0.9197 & 0.8558 \\
& $k_{1}\left(\right.$ day $\left.^{-1}\right)$ & 0.0088 & 0.0064 & 0.0058 \\
Higuchi & $R^{2}$ & 0.9609 & 0.9302 & 0.8656 \\
& $k_{\mathrm{H}}\left(\right.$ day $\left.^{-1 / 2}\right)$ & 0.0370 & 0.0320 & 0.0290 \\
Hixon-Crowell & $R^{2}$ & 0.9968 & 0.9925 & 0.9653 \\
Korsmeyer-Peppas & $k_{\mathrm{E}}\left(\right.$ day $\left.^{-1 / 3}\right)$ & 0.0034 & 0.0027 & 0.0025 \\
& $R^{2}$ & 0.8480 & 0.7496 & 0.6008 \\
& $k_{\mathrm{P}}\left(\right.$ day $\left.^{-n}\right)$ & 0.0371 & 0.0366 & 0.0351 \\
& $n$ & 0.4491 & 0.4398 & 0.4225 \\
& $R^{2}$ & 0.9978 & 0.9983 & 0.9953 \\
\hline
\end{tabular}

a up to 21 days

\section{CONCLUSIONS}

In conclusion, the proposed methodology may enable the development of new HAp-ciprofloxacin bone-implants for local antibiotic therapy in osteomyelitis, offering several advantages. Prolonged release of an antibiotic from these implants at the infected site may achieve elevated local antibiotic concentration, while minimizing the risk of systemic toxicity. The high antibiotic concentration in implants would help reduce the 
implant size, facilitating surgery and decreasing the hospitalization period. Again, this type of HAp-based bone delivery can be also developed for the treatment of osteoporosis, osseous tumors, trauma, osseous cancers, etc., in which local drug delivery aimed at filling defects in the skeleton is effective. Depending on the disease, various bioactive agents like antibiotics, anticancer agents, growth factors or other proteins, etc., can be locally released and may accelerate the process of bone regeneration.

Acknowledgements. - The authors are thankful to the Principal and Management of Gupta College of Technological Sciences, Asansol, India, for their kind permission and help in conducting this research work. They are also grateful to Dr. S. K. Dutta, Professor Emeritus, Gupta College of Technological Sciences, Asansol. They also thank Mr. H. S. Maji and Mr. P. Sarkar for their kind help during the FTIR data analysis and statistical work, respectively.

\section{REFERENCES}

1. D. R. Dirschl and L. C. Almekinders, Osteomyelitis. Common causes and treatment recommendations, Drugs 45 (1993) 29-43.

2. J. T. Mader, G. C. Landon and J. H. Calhoun, Antimicrobial treatment of osteomyelitis, Clin. Orthop. 295 (1993) 87-95.

3. A. K. Nayak, Hydroxyapatite synthesis methodologies: An overview, Int. J. ChemTechRes. 2 (2010) 903-907.

4. D.-S. Park, I.-S. Kim, H. Kim, A. H. Chou, B.-D. Hahn, L.-H. Li and S.-J. Hwang, Improved biocompatibility of hydroxyapatite thin film prepared by aerosol deposition, J. Biomater. Res. B: Appl. Biomater. 94 (2010) 353-358; DOI: 10.1002/jbm.b.31658.

5. Q. Z. Chen, C. T. Wong, W. W. Lu, K. M. C. Cheung, J. C. Y. Leong and K. D. K. Luk, Strengthening mechanisms of bone-bonding to crystalline hydroxyapatite in-vivo, Biomaterials 25 (2004) 4243-4254; DOI: 10.1016/j.biomaterials.2003.11.017.

6. D. J. A. Netz, P. Seoulveda, V. C. Pandolfelli, A. C. C. Spadaro, J. B. Alencastre, M. V. L. B. Bentley and J. M. Marchetti, Potential use of gelacasting hydroxyapatite porous ceramic as an implantable drug delivery system, Int. J. Pharm. 213 (2001) 117-125; DOI: 10.1016/S0378-5173(00) 00659-1.

7. B. D. Shenoy, N. Udupa and A. Nagarajkumari, Implantable drug delivery systems for centochromon, Indian J. Pharm. Sci. 59 (1997) 246-250.

8. W. Zafirau, D. Parker, W. Billotte and P. K. Bajpai, Development of a ceramic device for the continuous local delivery of steroids, Biomed. Sci. Instrum. 32 (1996) 63-70.

9. A. K. Nayak and K. K. Sen, Hydroxyapatite-ciprofloxacin minipellets for bone-implant delivery: Preparation, characterization, in-vitro drug adsorption and dissolution studies, Int. J. Drug Dev. Res. 1 (2009) 47-59.

10. H. H. Pham, P. Luo, F. Génin and A. K. Dash, Synthesis and characterization of hydroxyapatite-ciprofloxacin delivery systems by precipitation and spray drying technique, AAPS PharmSci Tech 3 (2002) Article 1; DOI: 10.1208/pt030101.

11. A. K. Nayak, A. Bhattacharya and K. K. Sen, Hydroxyapatite-antibiotic implantable minipellets for bacterial bone infections using precipitation technique: Preparation, characterization and in-vitro antibiotic release studies, J. Pharm. Res. 3 (2010) 53-59.

12. M. J. Maltesen, S. Bjerregaard, L. Hovgaard, S. Havelund and M. van de Weert, Quality by design-spray drying of insulin intended for inhalation, Eur. J. Pharm. Biopharm. 70 (2008) 828-838; DOI: $10.1016 /$ j.ejpb.2008.07.015. 
A. Kumar Nayak et al:: Development of hydroxyapatite-ciprofloxacin bone-implants using "Quality by design«, Acta Pharm. 61 (2011) 25-36.

13. T. Higuchi, Mechanisms of sustained action medications: Theoretical analysis of rate of release of solid drugs dispersed in solid matrices, J. Pharm. Sci. 52 (1963) 1145-1149; DOI: 10.1002/jps. 2600521210.

14. R. W. Korsmeyer, R. Gurny, E. Doelker, P. Buri and N. A. Peppas, Mechanisms of solute release from porous hydrophobic polymers, Int. J. Pharm. 15 (1983) 25-35; DOI: 10.1016/0378-5173(83) 90064-9.

15. R. A. Lionberger, S. L. Lee, L. Lee, A. Raw and L. X. Yu, Quality by design: Concepts for ANDAs, AAPS J. 10 (2008) 268-276; DOI: 10.1208/s12248-008-9026-7.

16. S. Verma, Y. Lan, R. Gokhale and D. J. Burgess, Quality by design approach to understand the process of nanosuspension preparation, Int. J. Pharm. 377 (2009) 185-198; DOI: 10.1016/j.ijpharm. 2009.05.006.

17. P. L. Granja, A. I. N. Silva, J. P. Borges, C. C. Barrias and I. F. Amaral, Preparation and characterization of injectable chitosan-hydroxyapatite microspheres, Key Eng. Mater. 254-256 (2004) 573-576.

18. G. Wu, G. Wang, X. Fu and L. Zhu, Synthesis, crystal structure, stacking effect and antibacterial studies of a novel quaternary copper (II) complex with quinolone, Molecules 8 (2003) 287-296; DOI: $10.3390 / 80200287$.

19. M. H. Santos, M. de Oliveira, P. de Freitas Souza, H. S. Mansur and W. L. Vasconcelos, Synthesis control and characterization of hydroxyapatite prepared by wet precipitation process, Mater. Res. 7 (2004) 625-630; DOI: 10.1590/S1516-14392004000400017.

20. R. Blagoeva and A. Nedev, Monolithic controlled delivery systems: Part II. Basic mathematical models, Bioautomation 5 (2006) 106-117.

$S A \check{Z} E T A K$

\section{Razvoj hidroksiapatit-ciprofloksacin implantata za kosti »dizajniranjem kvalitete«}

AMIT KUMAR NAYAK, BIBEK LAHA i KALYAN KUMAR SEN

U radu je opisan razvoj hidroksiapatit (HAp)-ciprofloksacin implantata za kosti »dizajniranjem kvalitete«. Učinak nezavisnih varijabli poput količine dodanog lijeka, brzine miješanja i udjela ortofosforne kiseline na koncentraciju lijeka u HAp-sustavu dobivenom precipitacijom optimiran je koristeći $2^{3}$ faktorijalno dizajniranje. Pomoću polinomske jednadžbe prvog reda određena je optimalna koncentracija lijeka u implantatima na bazi HAp. Dobiveni odgovori podudaraju se s predviđenim vrijednostima iz optimiranih formulacija. Novi implantati pripravljeni su koristeći različite omjere HAp i ciprofloksacina te $1,5 \%(\mathrm{~m} / \mathrm{V})$ guar gumu kao vezivo. Karakterizacija sustava za isporuku provedena je pomoću XRPD, FTIR spektroskopije i SEM. Ciprofloksacin je prisutan u amorfnom stanju čak pri najvišim koncentracijama $(76,6 \pm 0,5 \%, \mathrm{~m} / \mathrm{m})$. In vitro oslobađanje ciprofloksacina iz različitih implantata bilo je polagano tijekom nekoliko tjedana i dobro je koreliralo s Korsmeyer-Peppasovim modelom.

Ključne riječi: hidroksiapatit, ciprofloksacin, implantant za kosti, »dizajniranje kvalitete«, osteomielitis

Department of Pharmaceutics, Gupta College of Technological Sciences, Asansol-713301, India 